\title{
First records of the parti-coloured bat Vespertilio murinus (Chiroptera: Vespertilionidae) in the Pyrenees
}

\author{
Antton Alberdi ${ }^{1}$, Joxerra Aihartza ${ }^{1}$, Juan C. Albero ${ }^{2}$, \\ Ostaizka Aizpurua ${ }^{1}$, Adrià López-Baucells ${ }^{3,4}$, \\ Lídia Freixas ${ }^{3}$, Xavier Puig ${ }^{4}$, Carles Flaquer ${ }^{3}$ \\ and Inazio Garin ${ }^{1, *}$ \\ ${ }^{1}$ Department of Zoology and Animal Cell Biology, \\ University of the Basque Country, Box 644, E-48080 \\ Bilbao, Basque Country, Spain, e-mail: inazio.garin@ehu.es \\ ${ }^{2}$ Sodemasa, Avda. César Augusto 14, 7, 50004 Zaragoza, \\ Spain \\ ${ }^{3}$ Museu de Granollers-Ciències Naturals, Francesc Macià \\ 51, 08402 Granollers, Catalonia, Spain \\ ${ }^{4}$ Galanthus Association, Ctra. de Juià 46, 17460 Celrà, \\ Catalonia, Spain \\ *Corresponding author
}

Keywords: Iberian Peninsula; Pyrenees; summer; vagrants; Vespertilio murinus.

In summer 2009 and 2010, three male parti-coloured bats were captured in two different localities, Sahun and Pineta, in the Central Pyrenees. Located between Plan (Bielsa Valley) and Chía (Benasque Valley), Sahun is a deforested mountain pass over $2000 \mathrm{~m}$ a.s.l. $\left(42^{\circ} 34^{\prime} \mathrm{N}, 0^{\circ} 23^{\prime} \mathrm{E}\right)$, linking two mountainsides covered with natural forests and conifer plantations. One parti-coloured bat was captured there in 25th July 2009 with a 3-m-high net extended across almost the whole mountain pass. The bat was trapped $2.5 \mathrm{~m}$ above the ground. The heavy wind and the nature of the pass could have helped capture it, as this species usually flies $20-40 \mathrm{~m}$ above the ground. The other two animals were captured over a river pool in Pineta Valley $\left(42^{\circ} 39^{\prime} \mathrm{N}, 0^{\circ} 7^{\prime} \mathrm{E}\right)$, in Ordesa and Monte Perdido National Park, in 26th August 2010. The Cinca River runs through the glacial Pineta Valley at about $1200 \mathrm{~m}$ a.s.l., and it is surrounded by several of the highest mountains of the Pyrenees (more than $3000 \mathrm{~m}$ a.s.l.), with steep and craggy sides covered by deciduous and coniferous forests. We identified the species in situ on the basis of their general morphology, size (forearm lengths were 44.2, 46.8, and $47.2 \mathrm{~mm}$ ), fur colouration (the ventral part was clear, almost white, and the dorsal fur was much darker), and distinctive shapes of the face and tragus. Additionally, a fourth male parti-coloured bat was captured by another research team in a third locality, Barbarruens, near Seira $\left(42^{\circ} 29^{\prime} \mathrm{N}, 0^{\circ} 22^{\prime} \mathrm{E}\right)$, also in the Central Pyrenees, in 7th August 2010 (Lorente et al. 2010).

Subsequently, the potential presence of parti-coloured bats in the Eastern Pyrenees was modelled on the basis of the geographical and habitat features of the aforementioned localities in the Central Pyrenees. During the validation of the model in August 2011, a total of 13 males belonging to the parti-coloured bats were netted at dusk over a pond located at $1625 \mathrm{~m}$ a.s.l. in the south-facing slopes of the Cadí Natural Park ( $\left.42^{\circ} 14^{\prime} \mathrm{N}, 1^{\circ} 39^{\prime} \mathrm{E}\right)$.

These captures are the first confirmed records of particoloured bats in the Iberian Peninsula, but they are not actually the first data. In fact, Pastor (1859) reported the species in Asturias (northern Spain), and Galán (1997) reported two captures in San Sebastian (Basque Country). Nevertheless, these data are not considered reliable enough: in the former case, because there were frequent nomenclatorial confusions between Vespertilio murinus (Chiroptera: Vespertilionidae) and Myotis myotis (Borkhausen, 1797) among several 19th century authors, and in the latter, because of the lack of any consistent information to support the observations (Aihartza 2001, Palomo and Gisbert 2002, Palomo et al. 2007).

The distribution area of Vespertilio murinus extends from central and south-western Europe eastward to the coast of Asia (Rydell and Baagøe 1994). Even though the westernmost known breeding colonies are located in the Netherlands and Switzerland (Baagøe 2001, Jansen 2002, Jaberg and Blant 2003), historically, the western boundary of the species' distribution range has been set in the French regions of Burgundy, Rhône-Alpes, and adjacent Alps, owing to the frequent presence of male individuals there (Rydell and Baagøe 1994, Baagøe 2001) (Figure 1). However, outlying males have often been recorded in spring and summer in western Europe, in places far beyond the breeding range of the species. Thus, vagrant males have been found in northern Sweden (Ryberg 1947), central England (Corbet and Harris 1991), and the Faroe Islands (Stansfield 1966), and there is also a small number of recent records in central France: one individual was detected in 2002 (Boitier 2002), and at least six more male specimens were captured in late spring and summer since 1999 in Massif Central and surrounding areas (Markovets et al. 2004, Lemaire and Arthur 2007, LPO Aveyron 2008, Sané 2008, Disca and GCLR 2011) (Figure 1).

All the parti-coloured bats captured thus far in southwestern Europe beyond the breeding range of the species (namely, the Pyrenees and Massif Central) were male. Moreover, all the individuals were captured in spring and summer, although this could be due to the greater sampling effort in that period. That fact supports the idea that particoloured bats display a strong ecological dimorphism (Shine et al. 2002, Safi et al. 2007). In fact, in spring, Vespertilio 


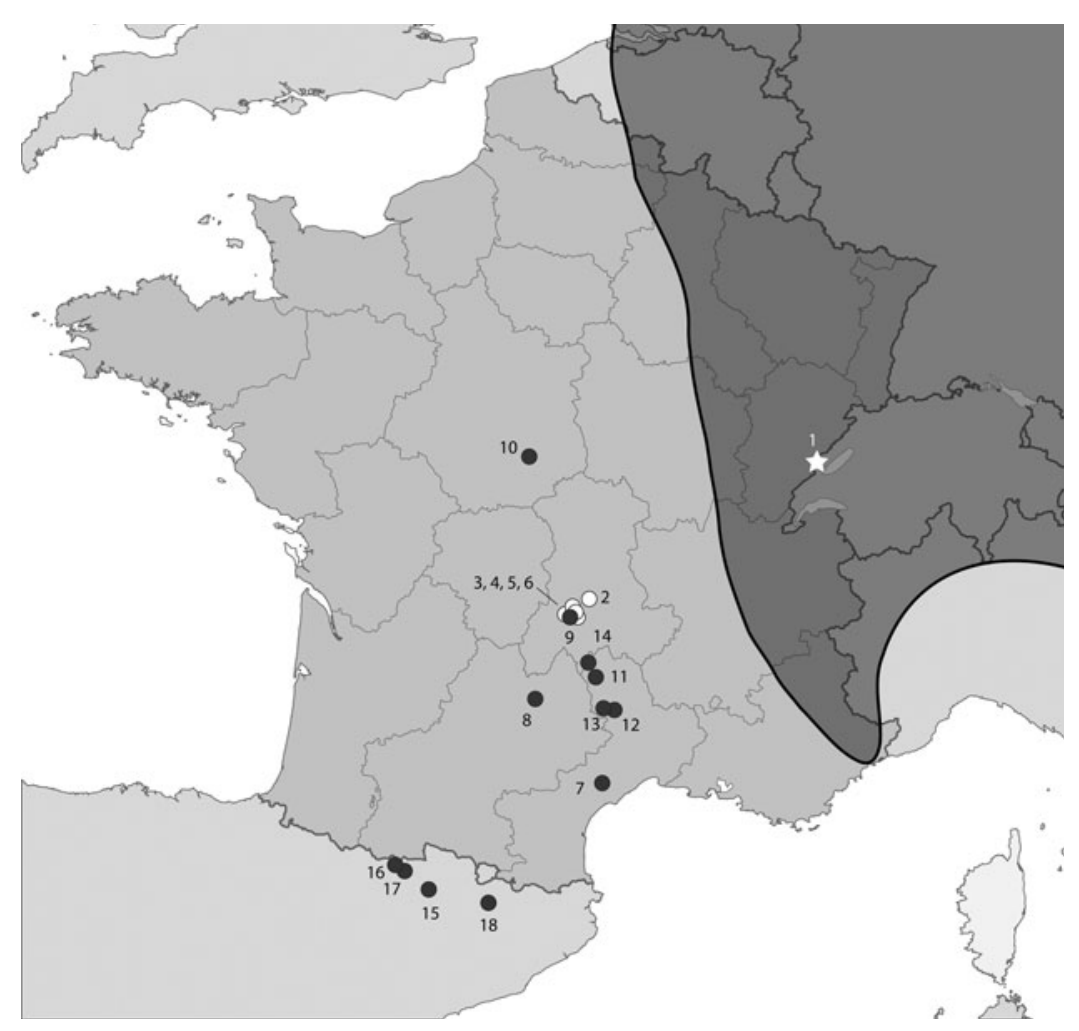

Figure 1 Locations of detections (white dots) and captures (black dots) of Vespertilio murinus reported in the last 10 years in central France and the Pyrenees. Nearest known nursery colony (1, white star), located in Neuchâtel, Switzerland (Jansen 2002, Jaberg and Blant 2003). Ultrasound detections in (2) Saurier in 2002 (Boitier 2002), and in (3) Lugarde, (4) Marchastel, (5) La Godivelle, and (6) Saint-Alyre-esMontagne in 2006 (Bernard pers. comm.). Captures reported in (7) Herault in 1999 (Markovets et al. 2004), (8) Druelle in 2004 (LPO Aveyron 2008), (9) Saint-Bonnet-près-Condat in 2006 (Bernard pers. comm.), (10) Bourges (Lemaire and Arthur 2007) and (11) Aubrac Lozérien plateaus in 2007 (Sané 2008), (12) Cevennes National Park and (13) Gorges de la Jonte in 2009 (Sané pers. comm.), and (14) Fournels (Disca and GCLR 2011) and (15) Seira in 2010 (Lorente et al. 2010). During this research, bats were captured in the Pyrenees in (16) Sahun mountain pass, (17) Pineta Valley, and (18) Cadí Natural Park. Shaded area shows the distribution area of V. murinus according to Dietz et al. (2009).

murinus live singly or in small groups (Rydell and Baagøe 1994), and, in contrast with other bat species, male particoloured bats often form large colonies containing up to 250 males (Baagøe 2001). Moreover, this species is known to migrate over long distances (Baagøe 2001, Hutterer et al. 2005), although up to this time, its presence in south-western Europe had gone unnoticed. Data herein reported suggest that seasonal male migrations to the south-western European area may not be as rare as previously supposed, and open the door to speculation: do those data belong to summering vagrant individuals, or do they reveal the presence of seasonal populations of males in Massif Central and the Pyrenees? Both are vast mountain ranges and are likely suitable shelter for summer populations of males. Besides, V. murinus could easily go unnoticed, as the most common bat-trapping techniques are not very effective in catching high-flying species such as parti-coloured bats, and the sampling effort has hitherto been poor in high mountain areas. The new records gathered during the last few years in Massif Central as a result of higher sampling intensity support the last statement.

A greater sampling effort and new records will be essential for determining the status of the parti-coloured male specimens in south-western Europe.

\section{Acknowledgements}

We wish to thank the Basque Government for the financial support.

\section{References}

Aihartza, J.R. 2001. Quirópteros de Araba, Bizkaia, y Gipuzkoa: distribución, ecología y conservación. Euskal Herriko Unibertsitatea, Bilbao. pp. 346.

Baagøe, H.J. 2001. Vespertilio murinus Linnaeus, 1758 - Zweifarbfledermaus. In: (F. Krapp, ed.) Handbuch der Säugetiere Europas. Aula Verlag, Weibelsheim, Germany. pp. 473-514.

Boitier, E. 2002. Un nouveau jalon occidental pour la Sérotine bicolore Vespertilio murinus en France: le Massif Central. Arvicola 14: 57.

Corbet, G. and S. Harris. 1991. The handbook of British mammals, 3rd ed. Blackwell Scientific Publications, Oxford, UK. pp. 588.

Dietz, C., O. Von Helversen and D. Nill. 2009. Bats of Britain, Europe and northwest Africa. A\&C Black, London. pp. 400.

Disca, T. and GCLR. 2011. Atlas des chauves-souris du midi méditerranéen. URL ONEM, http://www.onem-france.org/chiropteres/wakka.php?wiki=PagePrincipale.

Galán, C. 1997. Fauna de Quirópteros del País Vasco. Munibe 49: 77-100. 
Hutterer, R., T. Ivanova, C. Meyer-Cords and L. Rodrigues. 2005. Bat migrations in Europe. A review of banding data and literature. Natursch. Biol. Vielf. 28: 3-162+app.

Jaberg, C. and J.C. Blant. 2003. Spatio-temporal utilisation of roosts by the parti-coloured bat Vespertilio murinus L., 1758 in Switzerland. Mammal. Biol. 68: 341-350.

Jansen, E. 2002. The occurrence of the parti-coloured bat Vespertilio murinus in the Netherlands: a change of status. Bat Res. News 43: 90.

Lemaire, M. and L. Arthur. 2007. Une vingt et unième espèce de chauve-souris dans le Cher, la Sérotine bicolore. Symbioses 18: 26-28.

Lorente, L., J.C. Albero, J.L. Rivas and R. Jato. 2010. Nuevas observaciones de Murciélago bicolor (Vespertilio murinus L., 1758) en el Pirineo aragonés. Galemys 22: 53-54.

LPO Aveyron. 2008. Inventaire des Vertébrés de l'Aveyron: Faune sauvage de l'Aveyron. Atlas des vertébrés. Editions du Rouergue, Rodez, France. pp. 376.

Markovets, M.J., N.P. Zelenova and A.P. Shapoval. 2004. Beringung von Fledermäusen in der Biologschen Station Rybachy, 19572001. Nyctalus, N.S. 9: 259-268.

Palomo, L.J. and J. Gisbert. 2002. Atlas de los Mamíferos terrestres de España. Dirección General de Conservación de la NaturalezaSECEM-SECEMU, Madrid, Spain. pp. 564.
Palomo, L.J., J. Gisbert and J.C. Blanco. 2007. Atlas y Libro Rojo de los Mamíferos terrestres de España. Dirección General de la Biodiversidad-SECEM-SECEMU, Madrid, Spain. pp. 588.

Pastor, P. 1859. Apuntes sobre la fauna asturiana bajo sus aspectos científico e industrial. Imp. de Benito González, Oviedo, Spain. pp. 22.

Ryberg, O. 1947. Studies on bats and bat parasites. Svensk Natur, Stockholm, Sweden. pp. 330.

Rydell, J. and H.J. Baagøe. 1994. Vespertilio murinus. Mammal. Species 467: 1-6.

Safi, K., B. Konig and G. Kerth. 2007. Sex differences in population genetics, home range size and habitat use of the parti-colored bat (Vespertilio murinus, Linnaeus 1758) in Switzerland and their consequences for conservation. Biol. Conserv. 137: 28-36.

Sané, F. 2008. La Grande noctule Nyctalus lasiopterus (Schreber, 1780) en Lozère: résultats d'une semaine de suivi radio-télémetrique. Vespère 1: 21-35.

Shine, R., R.N. Reed, S. Shetty and H.G. Cogger. 2002. Relationships between sexual dimorphism and niche partitioning within a clade of sea-snakes (Laticaudinae). Oecologia 133: 45-53.

Stansfield, G. 1966. Parti-colored bat Vespertilio murinus L. from a North Sea drilling rig. J. Zool. (Lond.) 150: 491-492.

Received March 25, 2011; accepted December 6, 2011 